\title{
Corporate Social Responsibility: Review of Academic Literature
}

\author{
Tchuiendem Nelly Joel* Gabriel Kyeremeh \\ School of Accounting, Zhongnan University of Economics and Law, Wuhan, China
}

\begin{abstract}
CSR has gained more attention in recent years in both developing and developed countries and among the ancient debate questions concerning CSR is determining if it is important for companies to pay societal demands. Still date, this query has been a vital initiate for several studies, several researchers have stated that an answer to this question is yet to be found. The difference in CSR significances calls for a literature study so as to shed light on the debate and permit the drawing of a conclusion. Although for many developing countries like Cameroon, Nigeria, Ghana, CSR is not yet a priority for managers of firms, this study reveals several relationships between CSR and financial performance that include; positive, negative, U-shaped and even no relationship. Some studies have different opinion about CSR and performance but they are mostly outdated materials. There has been a lot of changes since the beginning of the CSR debate, hence one can say with conviction that "Good Ethics is Good Business".
\end{abstract}

Keywords: Corporate Social Responsibility (CSR), Financial performance, Literature review

DOI: $10.7176 /$ RJFA/11-18-05

Publication date:September $30^{\text {th }} 2020$

\section{Introduction}

The world has a number of problems existing in the environment and society and CSR could be used as a good device to sort out these problems up to some extend because businesses are running in the society by exploiting different resources. CSR is an obligation to the world \& people living inside and outside the business organizations. Every business has a number of contacts in the society such as owners, employees, customers, government, suppliers, environment etc. The obligations of these businesses include the satisfaction of these parties with its owner, this term is named corporate social responsibility of business. The debate regarding Corporate Social Responsibility (CSR) touches matters pertinent to the phenomena of the present economy. However, Wu (2002) argued that CSR was not really a debate nor was it a fad. Gossling and Vocht, (2007) stated that CSR comprised of the concept that companies need to meet the expectation of the society.

Barnett \& Solomon (2012) on a recently emerged stakeholder theory argued that the better a firm manages its relationships with its stakeholders, the more successful it will be over time. Delmas \& Toffle (2008) stated that although all stakeholders could possibly affect a company's performance, the mechanism differs and market constituents such as employees, customers, suppliers, creditors can directly cause a gap in economic rent by making disapproving economic choices. Henriques \& Sadorsky (1999) added that non-market constituents such as the general public, NGOs, media indirectly exert their influences by conveying information. Despite this diverse transmission instruments, Clarkson (1995) stated that the disappointment of any stakeholder group can possibly affect economic rents and even compromise an enterprise future. Thus, socially responsible activities is progressively more argued to be a requirement for guarding the bottom line and boosting shareholder value (Epstein \& Rejc-Buhovac, 2014).

Furthermore, Barnett \& Solomon (2006) added that increasing the number of investors are not only necessary at the financial performance level in an organization but also at valuing the way the organization meets their social responsibility. Corporate attention focus is thus shifted from a merely financial orientation to a much broader one.

Gossling (2003) mentioned that if the society can decide organizations have responsibilities towards stakeholders, we can thus expect organizations to be held responsible for their social performance. Freeman (1994) added that this does not only apply to their actions but as well as to the outcomes that results from their actions.

Friedman (1970) made a statement that is widely used and accepted today, he stated that the sole duty of managers was to increase stakeholder wealth. By stating this, he focused on a distinct feature of corporate and managerial duty. Thereby implying that the sole duty of managers is "to conduct the firm in accord to their desires in order to make abundant money as possible while following the elementary laws of the society".

Freeman (1994) did not agree to this and argued that they were a need of social performance to attain business legitimacy. He went ahead to say that director's fiduciary duty does not only account to shareholders but as well as to all stakeholders. Future studies on the link between social responsibility and financial performance was anticipated by Freeman's statement, and a positive association of the two was suggested in the long run.

The quarrels of the above-mentioned researchers could be used to discuss the concept of CSR today. The requirement for caution with respect to maturity of research evidence was stress by Ruf et al (2001) and they acknowledge that social performance will influence variations in economic development, national or local security and expectation of society. There's a great necessity to comprehend the consequences of CSR, Maron (2006) stated 
that entities have been encouraged to over towards socially responsible behaviors for both moral and practical business incentives. Doane (2005), Gauthier (2005) \& Stormer (2003) highlighted the ethical perceptive of studying CSR as it makes way for a more economic approach or at least a more business integrated approach.

There has been an on-going debate on Corporate Social Responsibility and Corporate Financial Performance (Alexander \& Buchholz, 1978). The outcomes vis-à-vis the nature of the relationship is still unclear. A positive relationship has been highlighted by some studies, others have a negative relationship, others no association and some demonstrated a curvilinear relationship. In spite of this variety, various studies such as, Margolis, Elfenbein, and Walsh (2007) and Orlitzky, Schmidt, and Rynes (2003) based on their meta-analysis concluded that there exist a positive association between CSR and performance. Thus, this study focuses on the literature review concerning the association of CSR and financial performance and identifies factors that determine this relationship. The research question is: According to literature review, what is the relationship between Corporate Social Responsibility and financial performance, and which factors determine this relationship?

\section{Corporate Social Responsibility}

A universal definition of CSR has not yet been accepted and the concept of CSR is quite imprecise at the moment. Several studies have been carried out on CSR, but as far as its definition and constituent dimensions are concerned, a consensus is yet to be found. Gossling and Vocht (2007) defined CSR as an obligation for entities to be accountable to their environments and their shareholders in aspects that go beyond financial traits. Dahlsrud (2008) highlighted 37 meanings of CSR in a comprehensive literature review. A great variation exists in the definition and perception of CSR. For instance, Friedman (1970) argued that "increasing profits is the sole social responsibility of a company while it obeys all the laws of the game". In contrast to this, Davis (1973) argued that "CSR goes beyond the narrow technical, economic and lawful requirements of an organization. The abovementioned definitions are both opposite, an organization is solely responsible to its shareholders as mentioned by the first definition whereas the second argues that both the interest of the shareholders and stakeholders have to be taken into consideration.

According to Canada (2009), CSR was defined as "the manner in which organizations take part in environmental, social and economic activities with their culture, morals, decision making and operations in a translucent manner and hence institute better practices in the organizations that help to create wealth and mend the Society". Jenkins (2009) defined CSR as the activities that contribute to sustainable development such as the integration of communal, economic and environmental management policies and strategies.

CSR is a set of engagements which is address to the social welfare and goes beyond the organization's interest and what is prerequisite by the law (Mc Williams and Siege 2001). Ollong (2014) went further to state that CSR is a relationship between the organization and the society and the role of the organization goes further than the mere provision of goods and services.

Bowen (1953) who is considered the father of the present concept of CSR, stated that businessmen have as an obligation to design policies, make decisions and follow guidelines to ensure they meet the objectives and values that are considered desirable to the society at large.

A precise definition was presented at the World Business Council for Sustainable Development: "Corporate Social Responsibility is the lasting responsibility of companies to act ethically and provide for economic development while refining personnel and their families' life quality and as well the society at large". This definition helped to put the concept of CSR in a broad nevertheless understandable viewpoint. Another definition that has been widely used by scholars was stated by Carrol (1979): "organizations have the social duty to incorporate the legal, ethical, economic and discretionary expectations of the society at a particular point in time".

CSR is therefore important at different levels within and outside organizations and its measurement is quite difficult. Three principle characteristics of CSR that could operate at different levels was distinguished by Wood (1991), they are thus: 1) Principle of legitimacy which operates at an established level. 2) Principle of public responsibility which operates at an organizational level and 3) Principal of managerial discretion which operates at an individual level. A social responsible action was seen by Goll and Rasheed (2004) as an effect of deliberate managerial choices which result from internal resolution process and most at times have a complex nature.

Different reasons motivate companies to participate in CSR actions. Lee \& Shin (2010) mentioned that the reasons varies from pure charitable action (desire to promote the welfare of others without any direct payback) to conformity with established pressures from exterior environment and explicit return benefits for example financial gains and better reputation. The following benefits attributed to a company for being socially responsible was summarized by Barnett and Salomon (2006): 1) excellent employees are obtained easily; 2) facilitate the creation of unanticipated opportunities; 3) attract resources easily; 4) the marketing of products and services becomes easier; and 5) it's an important source of competitive contest. Similarly, Weber (2008) as well highlighted five likely benefits of CSR actions for organization: 1) positive impact it has in an organization's image and reputation; 2) positive consequence it has on employee's motivation, and enrolment; 3) it reduces CSR-related risk; 4) cost savings; 5) it increases revenue due to higher sales. 
Although the aforementioned benefits are realized at the company's level, it's good to note that CSR as well has macro-level impacts. Skare \& Golja (2014) discovered that a larger portion of socially responsible companies in an economy are related to greater economic growth. Hence, CSR could be seen as an important element of economic development at the economy level.

\section{CSR and Financial performance relationship - Empirical evidence}

An important matter in corporate governance and management is determining the influence of CSR in an organization's performance more particularly the financial performance. Being socially responsible requires more charges, hence the conventional views that CSR is expensive. Instances of socially responsible engagements include: investment in pollution decline, benefits packages to employees, relationship with customers, philanthropic programs etc.

Flew (1973) and Gossling (2003) both mentioned that one of the first queries in moral philosophy was determining whether being a morally good person paid. In the same light, an important and old question in CSR could be formulated thus "Social behavior is good for the community, however does it pay? Brown (1998) and Gossling (2003) stated that moral behavior has not been proven theoretically to have any financial and economic benefits.

The concept of CSR and financial performance has been applied and correlated, diverse approaches have been used to measure the two. The first impression we have here is an arena of mixed evidence, some studies find a positive relationship, and others negative relationship as well as no relationship. The question therefore arises as to which relationship prevails; hence it appears important to consult empirical literature to determine a response to this question.

Erhemjamts et al., (2013), examined the determinants of CSR and its implication on firms' investment policy, organizational strategy and performance. They discovered that companies with higher performance, higher R\&D intensity, and stronger financial health were more expected to take part in CSR activities. They find a possible relationship between CSR and performance and suggested that socially responsible behaviors improve performance.

Burnett \& Hansen, (2008), explored the association between environmental performance and productive efficiency in the United States electric utility industry before and after the 1990 Clean Air Act Amendments. They used Data Envelopment Analysis (DEA) and they find that active environmental management can decrease environmental charge, hence lends provision for adopting an environmental cost management system.

Using a metal analysis, Allouche and Laroche (2005) investigated the link between Corporate Social Performance (CSP) and Corporate Financial Performance (CFP). The results were conclusive and revealed a positive association of CSP and CFP, they went ahead to argue that despite publication biases within the field, it was still possible to demonstrate a positive CSP-CFP relationship.

$\mathrm{Wu}$ (2006) more recently investigated the association of CSP and CFP and went ahead to investigate the role of the firm size as related to CSP. A positive relationship was revealed in his study which approves the view that the cost of being socially responsible are low and firms benefits from socially responsible behaviors. He as well discovered that the firm size has no effect on either CSP or CFP.

Several other studies such as Al-tuwaijri et al., (2004), Rodgers et al., (2013) as well identified a positive association of CSR and financial performance, thereby implying that being socially responsible improves the company's profitability. Moser \& Martin (2012) went ahead to add that, if CSR has a positive effect on financial performance, hence it is possible that socially responsible investments have a positive rather than negative impact on shareholder value. Hence, implying that CSR is as well promising to shareholders.

Peng \& Yang, (2014) investigated whether the impact of ownership concentration moderates the association of corporate social performance (CSP) and financial performance (FP). They used a unique, hand collected data set to measure CSP based on the sample of Taiwanese listed companies from the period 1996 to 2006 . The findings of this study provide firm support to the notion that the disagreement between control rights and the cash flow rights of controlling managers negatively moderates the relationship between social and short- and long-run FP, hence signifying a negative association of CSR and FP.

Baird, Geylani, \& Roberts, (2012), drew more light on the empirical relationship between CSR and CSP through the use of empirical models and different approaches to the CSP-CFP literature. They applied an advanced financial model to a uniquely built panel dataset and demonstrated that a significant relationship existed between CSP and CFP and the relationship is conditioned to firms' industry-specific context. Overall, their results showed a negative association of CSR and CFP. The negative association of CSR and financial performance however does not signify that firms should completely abandon social responsible actions. Moser \& Martin (2012), stated that it is good to be corporate citizens even when it is at the expense of shareholders.

Soana (2011) examined the ways CSR could be proxied and went ahead to investigate the possible association of Corporate Social Performance (CSP) and Corporate Financial Performance (CFP) in the banking zone by means of correlation methodology. Their main finding was that there was no statistical significant association between 


\section{CSP and CFP.}

Salama,Hussainey,\&Habbash (2010), examined the association between Corporate Environmental Disclosures (CED) and Earnings Management (EM). They used data from 245 UK non-financial firms for the period 1 April 2006 to 31 March 2007. They used three theoretical frameworks to identify the association of CER and EM precisely; signaling theory, agency theory and stake holder-legitimacy theory. Their main finding was that they exist no statistical association between the different measures of discretionary accruals and environmental disclosure. They also found that certain corporate governance aspects affect the association between CER and EM.

McWilliams \& Siegel (2000), examined the association between social and financial performance, they estimated the impact of CSR by regressing firm performance on corporate social performance and multiple other control variables. Their model was misspecified because it did not control for investment in R\&D, which is an important constituent of firm performance. They discovered that CSR had an impartial effect on financial performance

Alexander \& Buchholz (1978), examined the relationship between CSR and stock market performance of companies in the U.S for the period 1970-1974. They went ahead to calculate the risk measures and differential returns of the securities in the social responsibility analyses for a five-year sample period precisely 1970-1974 and a three-year sub period 1971-1973. Their main finding indicated a low insignificant association between social responsibility and the degree of risk-adjusted performance.

Barnett \& Salomon (2012), examined the opposing literatures on the association of CSP and CFP in order to hypothesize that the CSP-CFP relationship is U-shaped. The results of this study supported the hypothesis and they found out that companies with lower CSP had higher CFP compared to firms with moderate CSP, whereas firms with higher CSP had the highest CFP. A prior study by Bowman \& haire (1975) interestingly find an inverted U-shaped relationship of CSR and financial performance. This implied that mediocre CSR is associated to the highest performance while lower and higher CSR are associated to lower performance.

All together, we realize that the empirical literature does not provide a conclusive evidence on the CSR and Financial performance relationship. Identifying the factors that influence CSR and financial performance relationship may thus stimulates companies to become more involved in sustainability and CSR matters. Vogel (2005), stated that the identification of a positive association of CSR and financial performance does not pay off for CSR investment for every individual organization. However, a positive relationship of CSR and financial performance will indicate the likely pay off of investment in CSR activities. Thus, indicating that the argument that CSR constitutes a cost for companies and a waste of money without being related to profit is not a valid argument. Both the literature on CSR and financial performance as well as CSP and CFP have been inconclusive. Several researchers have proposed possible clarifications for these unconvincing findings. They include: 1) poor theoretical basis of the CSR concept (Ruf et al., 2001); 2) exclusion of important variables in the model (McWilliams \& Siegel, 2000; 3) absence of clear direction of casaulity (Waddock \& Graves, 1997); 4) measurement issues and sampling limitations (Davidson \& Worrel, 1990; Griffin \& Mahon, 1997). All of these point for a broader look at the CSR and financial performance link and a greater investigation of the existing literature.

\section{Corporate Social Responsibility measuring approaches review}

Dahlsrud (2008), and Carroll (1979) outlined two reasons why CSR measurement is complicated. Firstly, there is a missing consensus on the theoretical meaning of the notion of CSR and lastly the CSR notion is multidimensional with quite heterogeneous dimensions. Hence, the use of various approaches to measure CSR in the literature is not unexpected owing to the difficulty and lack of consensus of the concept. The different approaches used in the CSR measurement could be summarized as thus: 1) questionnaire-based analysis; 2) one-dimensional measures and 3) reputation indices.

\subsection{Questionnaire-based analysis}

In a questionnaire-based analysis, the researcher ought to send questionnaires to different respondents or probably interview them, all in the aim of collecting primary data about CSR. Aupperle, Carroll, and Hatfield (1985) conducted the oldest questionnaire analysis as far as CSR is concerned. They used Carroll's (1979) measurement instruments which comprises of legal, ethical, economic, and discretionary and further added 80 elements which was arranged in 20 groups of statements, every group contained four statements that is one for each element of CSR. They asked their respondents to assign up to 10 points respectively for each group of statement on CSR. While studying the association of CSR and CFP, Rettab, Brik, and Mellahi (2009) used questionnaires to collect information on CSR and CFP. In a more current research, Gallardo-Vázquez and Sanchez-Hernandez (2014) established a CSR measurement scale, which was used to evaluate the economic, social and environmental aspect of CSR. The main advantage of this method of measurement is that it makes available a great level of flexibility for the researchers, they are as well relatively easy to analyze and simple to administer. The main disadvantage is the response bias. Cadez \& Czerny (2016), mentioned that bias practically occurs at two dimensions, and they 
occur as more socially responsible organizations are likely to respond to questionnaires compared to less socially responsible organizations. Epstein \& Rejc-Buhovac (2014), went further to say that attitude bias is likely to occur when socially desired answers are provided by respondents but their real actions differs. A way of overcoming this disadvantage is by collecting data both from the firm and its stakeholders.

\subsection{One-dimensional measures}

This measurement type only handles a single element of CSR, for instance philanthropy and environmental activities. The following studies gave examples of philanthropy to include; donations (Lin, Yang, \& Liou, 2009), growth in generous contributions (Lev, Petrovits, \& Radhakrishnan, 2010), and public health procedures (NaranjoGil, Sánchez-Expósito, \& Gómez-Ruiz, 2016). Instances of environmental management include; pollution control investment data (Peng \& Yang, 2014), the ratio of poisonous waste reprocessed to total poisonous waste engendered (Al-Tuwaijri, Christensen, \& Hughes, 2004), implementation of global environmental standard (Dowell, Hart, \& Yeung, 2000) and environmental proactivity (Primc \& Čater, 2015). The main advantage of this method is data accessibility across different companies; thus, data collection efforts are minimized. Carroll (1979), further added that the use of this measurement is problematic because the CSR notion is multidimensional, for instance a specific firm may neglect one dimension, probably employees but on the other hand it's more inclined to another dimension let's say environmental issues.

\subsection{Reputation indices}

This method remains the best method for measuring CSR. Major indices used by various researches include; MSC KLD 400 social index which was used by Erhemjamts, Li, \& Venkateswaran, (2013), Dow Jones Sustainability Index used by Škare \& Golja, (2012), Fortune magazine reputation index used by Preston \& O'Bannon, (1997), and lastly the Vigeo Index used by Girerd-Potin, Jimenez-Garcès, \& Louvet, (2014). The multidimensional nature of CSR is recognized by the reputation indices, Griffin and Mahon (1997) in their study compared MSCI KLD and Fortune indices and they discovered that the both indices were quite similar to each other. Coombs \& Gilley (2005), stated that the most used measuring index remains MSCI KLD because of its completeness and prominent information on shareholder management. However, Johnson \& Houston (2000), McGuire, Sundgren, \& Schneeweis (1988) argued this fact and said that Fortune indices was the most comprehensive and comparable index. The key benefit of the reputation indices is the data availability across companies. This method however has several limitations. Graafland, Eijffinger, \& SmidJohan (2004), Unerman, (2000), gave one weakness to be the fact that the method is practically used by organizations that have their own schedules and do not certainly use scientific methods. Another weakness entails the geographic area, most of the indices simply cover a particular region or country. Moreover, some reputation indices such as MSCI KLD index and the Dow Jones Sustainability index do not include organizations operating in industries considered to be non-sustainable such as tobacco, firearms, alcohol etc. Adam \& Shavit, (2008) concluded that as a result of this, many socially and environmentally responsible companies may not make it to the list due to their size and geographic location.

\section{Financial Performance Measuring Approach Review}

Accounting based indicators and market-based indicators are the most frequently used type of measurement for CSR. Accounting based indictors include: Return on asset (ROA), Return on equity (ROE), Return on capital employed (ROCE), Return on sales (ROS), net operating income, net income, and Zmijewski score. One of the disadvantages of this measure is that it's historical. Al-Tuwaijri et al., (2004), stated that while complete categories such as net profit fail to take the firm's size into consideration, relativized accounting ratios such as ROA tend to be biased if the sample includes firms from diverse industries.

Market based indicators include: stock returns, market value of a company and change in stock returns. The biggest throwback of this measure is their availability only for publicly listed firms. Moreover, McGuire et al., (1988) added that market-based indicators unavoidably incorporate systematic that is non-firm-specific market characteristics while accounting-based indicators are more subtle to the firm's specific characteristics that is its unsystematic perception of CSR.

It's good to note that some authors such as Garcia-Castro, Ariño, \& Canela, (2010), Rodgers, Choy, \& Guiral,(2013), have combined both measures that is accounting-based and market-based measures by using indicators such as the Tobin's Q (market value divided by total assets) or MVA (market value minus book value of equity and debt). Peng and Yang (2014) in a recent study integrated several financial performance measures such as ROA, ROE, and Earnings per share using factor analysis. Furthermore, Rodgers et al., (2013) in his research used the financial health of a company which he measured using Zmijewski score as a proxy for accounting-based organization profitability. It's noteworthy that in recent years, they have been a great trend of using more than one measure of financial performance. 


\section{Conclusion}

The impact of CSR on financial performance has remained a substantial issue for directors as stated by Cochran \& Wood, (1984). Empirical literature fails to offer convincing proof despite all enquiry into the nature of this relationship. This literature review focused on the association of CSR and financial performance, and the factors that influence such a relationship.

Different studies had different results regarding the association of CSR and financial performance, such as positive, negative, U-shaped and even in some cases no relationship. In concordance with previous research, we realized a great inconsistency in the manner researchers measured the CSR and financial performance relationship. Several methods used for CSR measurement include: questionnaire-based analysis; one-dimensional measures and reputation indices, measures for financial performance include the accounting-based indicators and market-based indicators.

Conclusively, the definition of CSR and financial performance, methodology used for CSR measurement and financial performance, the manner of testing the relationship between them could therefore be named as factors that influence the relationship between CSR and financial performance.

\section{References}

Abbott, W., \& Monsen, R. J. (1979). On the measurement of corporate social responsibility: Self- reported disclosures as a method of measuring corporate social involvement. Academy of Management Journal, 22, 501-515.

Accounting, Organization and Society, 33, 551-581. doi:10.1016/j.aos.2007.06.002 Cadez, S., \& Czerny, A. (2016). Climate change mitigation strategies in carbon intensive firms. Journal of Cleaner Production, 112 , 4132-4143. doi:10.1016/j.jclepro.2015.07.099

Adam, A., \& Shavit, T. (2008). How can a ratings-based method for assessing Corporate Social Responsibility (CSR) provide an incentive to firms excluded from socially responsible investment indices to invest in CSR? Journal of Business Ethics, 82, 899-905. doi:10.1007/s10551-007-96004

Alexander, G. J., \& Buchholz, R. A. (1978). Corporate social responsibility and stock market performance. Academy of Management Journal, 21, 479-486.

Allouche, J. and P. Laroche: 2005, 'A Meta-Analytical Investigation of the Relationship Between Corporate Social and Financial Performance', Revue de Gestion des Ressources Humaines 57(1), 8-41.

Al-Tuwaijri, S. A., Christensen, T. E., \& Hughes II, K. E. (2004). The relations among environmental disclosure, environmental performance, and economic performance: A simultaneous equations approach. Accounting, Organization and Society, 29, 447-471. Retrieved from http://dx.DOI. org/10.1016/S0361-3682(03)00032-1

Aras, G., Aybars, A., \& Kutlu, O. (2010). Investigating the relationship between corporate social responsibility and financial performance in emerging markets. Managing corporate performance, 59, $229-254$. doi:10.1108/17410401011023573

Arlow, P. and R. Ackelsberg: 1991, 'A Small Firm Planning Survey: Business Goals, Social Responsibility, and Financial Performance', Akron Business and Economic Review 22(2), 161-172.

Artiach, T., Lee, D., Nelson, D., \& Walker, J. (2010). The determinants of corporate sustainability performance. Accounting and Finance, 50, 31-51. doi:10.1111/j.1467-629X.2009.00315.x

Aupperle, K. E., Carroll, A. B., \& Hatfield, J. D. (1985). An empirical examination of the relationship between corporate social responsibility and profitability. Academy of Management Journal, 28, 446-463.

Aver, B., \& Cadez, S. (2009). Management accountants' participation in strategic management

Baird, P. L., Geylani, P. C., \& Roberts, J. A. (2012). Corporate social and financial performance

Balabanis, G., H. C. Philips andj. Lyall: 1998, 'Corporate Social Responsibility and Economic Performance in the Top British Companies: Are They Linked?', European Business Review 98(1), 25-42.

Barnett, M. L. and R. M. Salomon: 2006, 'Beyond Dichotomy: The Curvilinear Relationship Between Social Responsibility and Financial Performance', Strategic Management Journal 27(11), 1101-1156.

Barnett, M. L., \& Salomon, R. M. (2006). Beyond dichotomy: The curvilinear relationship between social responsibility and financial performance. Strategic Management Journal, 27, 1101-1122. doi: $10.1002 / \mathrm{smj} .557$

Barnett, M. L., \& Salomon, R. M. (2012). Does it pay to be really good? Addressing the shape of the relationship between social and financial performance. Strategic Management Journal, 33, 1304-1320. doi: $10.1002 /$ smj. 1980

Becchetti, L., \& Trovato, G. (2011). Corporate social responsibility and firm efficiency: A latent class stochastic frontier analysis. Journal of Productivity Analysis, 36, 231-246. doi:10.1007/s11123-011-0207-5

Blacconiere, W. G. and D. M. Patten: 1994, 'Environmental Disclosures, Regulatory Costs, and Changes in Firm Value', Journal of Accounting and Economics 18(3), 357-377.

Bowman, E. H., \& Haire, M. (1975). A strategic posture toward corporate social responsibility. California Management Review, 18, 49-58. doi:10.2307/41164638 
Boyle, E. J., M. M. Higgins and S. G. Rhee: 1997, 'Stock Market Reaction to Ethical Initiatives of Defence Contractors: Theory and Evidence', Critical Perspectives on Accounting 8(6), 541-561.

Brammer, S., C. Brooks and S. Pavelin: 2006, 'Corporate Social Performance and Stock Returns UK Evidence from Disaggregate Measures', Financial Management 35(3), 97-116.

Brown, B.: 1998, 'Do Stock Market Investors Reward Companies with Reputations for Social Performance?', Corporate Reputation Review 1(3), 271-280.

Burnett, R., \& Hansen, D. (2008). Ecoefficiency: Defining a role for environmental cost management.

Cadez, S., \& Guilding, C. (Forthcoming). Examining distinct carbon cost structures and climate change abatement strategies in $\mathrm{CO} 2$ polluting firms. Accounting, Auditing \& Accountability Journal.

Carrol, A. B.: 1979, A Three-Dimensional Conceptual Model of Corporate Performance', The Academy of Management Review 4(4), 497-505.

Carroll, A. B. (1979). A three dimensional conceptual model of corporate social performance. Academy of Management Review, 4, 497-505.

Carter, C. R., R. J. Auskalnis and C. L. Ketchum: 1999, 'Purchasing from Minority Business Enterprises: Key Success Factors', Journal of Supply Chain Management 35(1), 28-32.

Carter, C. R., R. Kale and C. M. Grimm: 2000, 'Environmental Purchasing and Firm Performance: An Empirical Investigation', Transportation Research 36(E), 219-228.

Chand, M.: 2006, 'The Relationship Between Corporate Social Performance and Corporate Financial Performance: Industry Type as a Boundary Condition', The Business Review 5(1), 240-245.

Chen, 1., Feldmann, A., \& Tang, O. (2015). The relationship between disclosure of corporate social performance and financial performance: Evidence from GRI reports in manufacturing industry. InternationalJournal of Production Economics, 170, 445-456. doi:10.1016/j.ijpe.2015.04.004

Clarkson, M. B. E. (1995). A stakeholder framework for analyzing and evaluating corporate social performance. Academy of Management Review, 20, 92-117.

Cochran, P. L., \& Wood, R. A. (1984). Corporate social responsibility and financial performance. Academy of Management Journal, 27, 42-56.

Cohen, B. and M. I. Winn: 2007, 'Market Imperfections, Opportunity and Sustainable Entrepreneurship', Journal of Business Venturing 22(1), 29-49

Coombs, J. E., \& Gilley, K. M. (2005). Stakeholder management as a predictor of CEO compensation: Main effects and interactions with financial performance. Strategic Management Journal, 26, 824-840. doi:10.1002/smj.476

Crane, A., McWilliams, A., Matten, D., Moon, J., \& Siegel, D. (2008). The corporate social responsibility agenda. In A. Crane, A. McWilliams, D. Matten, J. Moon, \& D. Siegel (Eds.), The Oxford handbook of corporate social responsibility (pp. 3-18). New York, NY: Oxford University Press.

Dahlsrud, A. (2008). How corporate social responsibility is defined: An analysis of 37 definitions. Corporate Social Responsibility and Environmental Management, 15, 1-13. doi:10.1002/csr.132

Davidson, W. N. Ill and D. L. Worrell: 1990, 'A Comparison and Test of the Use of Accounting and Stock Market Data in Relating Corporate Social Responsibility and Financial Performance', Akron Business and Economic Review 21(3), 7-19.

Davidson, W. N., \& Worrell, D. L. (1990). A comparison and test of the use of accounting and stock market data in relating corporate social responsibility and financial performance. Akron Business and Economic Review, $21,7-19$.

Davis, K. (1973). The case for and against business assumption of social responsibilities. Academy of Management Journal, 16, 312-322.

De Bakker, F. G.A.,P. Groenewegen and F. den Hond: 2005, 'A Bibliometric Analysis of 30 Years of Research and Theory on Corporate Social Responsibility and Corporate Social Performance', Business and Society 44(3), 283-317.

Deckop, J. R., Merriman, K. K., \& Gupta, S. (2006). The effects of CEO pay structure on corporate social performance. Journal of Management, 32, 329-342. doi:10.1177/0149206305280113

Delmas, M. A., \& Toffel, M. W. (2008). Organization responses to environmental demands: Opening the black box. Strategic Management Journal, 29, 1027-1055. doi:10.1002/smj.701

Dhaliwal, D. S., Radhakrishnan, S., Tsang, A., \& Yang, Y. G. (2012). Nonfinancial disclosure and analyst forecast accuracy. International Evidence on Corporate Social Responsibility Disclosure, The Accounting Review, 87, 723-759. doi:10.2308/accr-10218

Doane, D.: 2005, The Myth of CSR', Stanford Social Innovation Review 3(3), 22-29. Dowell, G.,S. Hart and B. Yeung: 2000, 'Do Corporate Global Environment Standards Create or Destroy Market Value?', Management Science 46(8), 1059-1074. Flew, A.: 1973, 'Must Morality Pay or What Socrates Should Have Said to Thrasymachus', in C. L. Carter (ed.), Skepticism and Moral Principles (New University Press, Evanston), pp. 21-47. 
Dowell, G., Hart, S., \& Yeung, B. (2000). Do corporate global environmental standards create or destroy market value? Management Science, 46, 1059-1074. doi:10.1287/mnsc.46.8.1059.12030

Ducassy, I. (2013). Does corporate social responsibility pay off in times of crisis? An Alternative Perspective on The Relation Between Financial and Corporate Social Performance, Corporate Social Responsibility and Environmental Management, 20, 157-167. doi:10.1002/csr.1282

Frederick, W. C: 1994, 'From CSR1 to CSR2', Business and Society 33(2), 150-164. Freedman, M. and A. J. Stagliano: 1991, 'Differences in Social-Cost Disclosures: A Market Test of Investor Reactions', Accounting Auditing and Accountability Jour nal 4(1), 68-83.

Freeman, R. E.: 1994, 'The Politics of Stakeholder Theory: Some Future Directions', Business Ethics Quarterly 4(4), 409-421.

Friedman, M.: 1970, 'The Social Responsibility Of Business is to Increase Its Profits', New York Times, 13 September 1970, pp. 122-126.

Frooman, J.: 1997, 'Socially Irresponsible and Illegal Behavior and Shareholder Wealth', Business and Society 36(3), 221-249.

Garriga, E. and D. Mele: 2004, 'Corporate Social Responsibility Theories: Mapping the Territory', Journal of Business Ethics 53(1-2), 51-71.

Gauthier, C: 2005, 'Measuring Corporate Social and Environmental Performance: The Extended Life Cycle Assessment', Journal of Business Ethics 59(1), 199 ?206.

Goll, I. and A. A. Rasheed: 2004, 'The Moderating Environmental Munificence and Dynamism on the Relationship Between Discretionary Social Responsibility and Firm Performance', Journal of Business Ethics 49(1), 4154.

Gossling, T.: 2003, 'The Price of Morality. An Analysis of Personality, Moral Behaviour, and Social Rules in Economic Terms', Journal of Business Ethics 45(1-2), 121-131.

processes: A cross industry comparisons. Journal for East European Management Studies, 14, 310-322.

re-examined: Industry effects in a linear mixed model analysis. Journal of Business Ethics, 109, $367-388$. doi:10.1007/s10551-011-1135-z

Van Beurden, P., \& Gössling, T. (2008). The worth of values - A literature review on the relation between corporate social and financial performance. Journal of Business Ethics, 82, 407-424. doi:10.1007/s10551008-9894-x 